Fry, Z. B. (1963). Development and evaluation of soil bearing capacity, foundation of structures. Waterways Experimental Station Technical Report No. 3-632, Report 1.

Kaldjian, M. J. (1969). Discussion on Design procedures for dynamically loaded foundations. Proc. Soil Mech. Fdns Div. Am. Soc. Civ. Engrs 95, SM1, 364-366.

Lysmer, J. \& Kuhlemeyer, R. L. (1969). Finite dynamic model for infinite media. Proc. Eng. Mech. Div. Am. Soc. Civ. Engrs 95, EM4, 859-877.

Lysmer, J. \& Kuhlemeyer, R. L. (1971). Closure to discussions. Proc. Eng. Mech. Div. Am. Soc. Civ. Engrs 95, Feb., 129-131.

Novak, M. (1960). The vibration of massive foundations on soil. International Association for Bridge and Constructural Engineers, Publication No. 20, 263-281.

Novak, M. (1970). Prediction of footing vibrations. Proc. Soil Mech. Fdns Div. Am. Soc. Civ. Engrs 96, SM3, 837-861.

Novak, M. (1971). Data reduction from nonlinear response curves. Proc. Eng. Mech. Div. Am. Soc. Civ. Engrs 97, EM4, 1187-1204.

Novak, M. \& Beredugo, Y. (1971). The effect of embedment on footing vibrations. Proc. 1st Can. Conf. on Earthquake Engng Res., University of British Columbia, Vancouver, BC, Paper No. 7, 7-1-7-15.

\title{
$\geqslant \quad$ Undrained creep behaviour of a coastal organic silty clay
}

\author{
ARULANANDAN, K., SHEN, C. K. and YOUNG, R. B. (1971). Géotechnique 21, No. 4, 359-375.
}

\section{R. P. Kulkarni}

The discussion is limited to saturated consolidated clays (in the laboratory or field) tested in triaxial shear apparatus by a controlled stress rate method, i.e. either by the test procedure given by the Authors or that suggested by Tan (1961), to determine its creep strength. In order to determine the creep strength of a soil sample some conditions have to be fulfilled by the test procedure followed and by the soil sample tested by that procedure.

The creep strength of a soil is the shear resistance as measured by the principal stress difference, at which the rate of strain at steady state creep condition (Mitchell et al., 1965) is neither accelerating nor decelerating but is constant independent of the time for which the sustained constant shear stress is acting.

The prerequisite for satisfying the above definition of creep shear strength of soil is that it should have a structure (Lambe, 1953) which would not change with deformation of the soil when subjected to a sustained constant shear stress. If the structure of soil would change with deformation so that stronger contacts between clay particles would develop then the rate of strain would decelerate. On the other hand, with deformation, if weaker contacts develop so that the strength of the soil decreases with deformation and time, then the rate of strain would be accelerating. It seems that the only type of structure that would not change with deformation, and time, is the ideal dispersed structure. The clay soil with an ideal dispersed structure has flat surfaces of clay particles oriented parallel to each other and to the potential plane of failure. The distance between clay particles is a function of the normal stress acting on the potential plane of failure. (The possibility of change in a structure because of change in an electrolyte content of pore water is excluded.)

The shear strength of the soil of an ideal dispersed structure is its creep shear strength. The creep shear strength of soil is quantitatively the same as that of its residual shear strength (Skempton, 1964). Qualitatively the residual shear strength of soil is its after-failure strength (Hvorslev, 1960) whereas the creep shear strength is such that any shear stress of magnitude less than it would be unable to bring shear failure of soil irrespective of the time for which it is acting.

In order to find the creep shear strength of a clay soil in the laboratory, an ideal dispersed structure should be developed in the zone of failure before the failure of the soil occurs, i.e. the 
structure of the soil developed in the zone of failure should be ideally dispersed before a stress level equal to the shear strength of the ideally dispersed clay soil is applied. This is the condition which a test procedure followed to determine creep shear strength of soil should satisfy.

The limitations of conducting a controlled stress rate test in the triaxial apparatus so as to form an ideal dispersed structure of soil before it fails, within the short duration of the test, require the following conditions to be satisfied.

(a) It is preferable to consolidate soil samples under the $\mathrm{k}_{0}$ condition as this leads to better orientation of clay particles (Martin, 1965).

(b) The soil should be highly plastic as a small consolidation stress develops comparatively large consolidation strains leading again to the orientation of clay particles.

(c) The amount of clay content in the soil is more than $43 \%$ (Borowicka, 1965 and Mitchell et al., 1965) so that the shear resistance offered by the soil, at creep condition is that of clay particles alone, and there would be no obstruction by coarse grained particles to the orientation of clay particles.

(d) The soil is non-thixotropic and insensitive.

(e) The soil is not overconsolidated from large past consolidation pressures acting over, geologically long times, as it is difficult to bring clay particles of such soils at a distance from each other commensurate to the existing normal stresses acting on the soil within the short duration of the laboratory test.

\section{REFERENCES}

Borowicka, H. (1965). The influence of the colloidal content on the shear strength of clay. Proc. 6th Int. Conf. Soil Mech., Montreal 1, 175-178.

Hvorslev, M. J. (1960). Physical components of the shear strength of saturated clays. Research Conference on Shear Strength of Cohesive Soils, Colorado 169-273.

Lambe, T. W. (1953). The structure of inorganic soil. Proc. Am. Soc. Civ. Engrs, Separate 315, Oct.

Martin, R. T. (1965). Quantitative fabric of consolidated kaolinite. Research in Earth Physics Phase Report No. 4, MIT Report R65-47.

Mitchell, J. K., Seed, H. B. \& Paduana, J. (1965). The creep deformation and strength characteristics of soils under the action of sustained stress. Report No. TE65-8 to the USBR, Department of the Interior, University of California, Berkeley.

Skempton, A. W. (1964). Long-term stability of clay slopes. Géotechnique 14, No. 2, 77-100.

Tan, T. K. (1961). Discussion of Section 1. Soil properties and their measurements. Proc. 5th Int. Conf. Soil Mech., Paris 3, 141.

\section{Inherent anisotropy in a sand}

ARTHUR, J. R. F. and MENZIES, B. K. (1972). Géotechnique 22, No. 1, 115-128

\section{J. R. F. Arthur and A. B. Phillips}

New shear testing apparatuses need to be evaluated by comparing results obtained from them with those from well tried apparatuses. The Authors have included a comparative result from the conventional 'free end' triaxial apparatus (Figs 20 and 21) but this comparison does not include the inherent anisotropic cffect. In view of the general criticism of the original design by Ko and Scott (1967) (Green, 1967; Arthur and Menzies, 1968 and Bell, 1968), it was considered essential to extend the comparison to ensure that the new version of the cell avoided earlier deficiencies. Consequently, some parallel tests were run with a prismatic sample in a conventional 'free end' triaxial cell. The base of this cell and a sample are 